\title{
Evolution of a Nanocrystalline Structure of the Cobalt Metal in Annealing
}

\author{
L.A. Gabdrakhmanova ${ }^{1}$, K.M. Mukasheve,,, F.F. Umarov³, A.D. Muradov², G.Sh. Yar-Mukhamedova² \\ 1 Bashkir State University, Ufa, Bashkortostan, Russia \\ 2 Al-Farabi Kazakh National University, Almaty, Kazakhstan \\ ${ }^{3}$ Kazakh-British Technical University, Almaty, Kazakhstan
}

(Received 29 July 2020; revised manuscript received 20 December 2020; published online 25 December 2020)

\begin{abstract}
It is shown that the boundaries of grains formed during severe plastic deformation of cobalt are highangle, nonequilibrium, adjacent to distorted regions of the crystal lattice. These distortions are caused by the fields of elastic stresses introduced by grain boundary dislocations. The density of dislocations in the bulk of nanocrystals reaches $1010 \mathrm{~cm}^{2}$. The large length of nonequilibrium boundaries and the high density of defects play a decisive role in the formation of physical and mechanical properties and determine the low thermal stability of nanocrystalline materials: grain growth begins at relatively low temperatures during the recovery of the cobalt structure. This process develops smoothly up to $300{ }^{\circ} \mathrm{C}$. A sharp change in these properties occurs during recrystallization at $T>300^{\circ} \mathrm{C}$ and then they practically do not change. Above $T>400{ }^{\circ} \mathrm{C}$, the cobalt structure became completely recrystallized and further coarsening of grains is observed. In this case, the abnormal growth of perfect grains occurs due to the absorption of small imperfect cells. As a result of the redistribution and annihilation of dislocations in the boundaries and in the volume of grains, the processes of recrystallization occur according to the diffusion mechanism.
\end{abstract}

Keywords: Nanocrystals, Diffusion, Grain growth, Defects, Dislocations, Recrystallization, Activation energy.

DOI: $10.21272 /$ jnep.12(6).06027

PACS numbers: 61.46.Df, 71.20.Gj

\section{INTRODUCTION}

Nanocrystalline (NC) materials are of great scientific and practical interest because of their unusual physical properties [1-3]. With the transition to the NC state, the diffusion coefficient increases by several orders of magnitude compared with other materials [4-8]. At the same time, NC materials are not thermally stable. Upon heating, relaxation develops in such materials, leading to a gradual transition to a coarsecrystalline state and loss of physical properties due to the NC structure. Recent research results suggest that the special properties of NC materials are caused not only by the large length of the internal interfaces, but also by the special nonequilibrium state of the grain boundaries. Therefore, an understanding of the behavior of NC materials is closely related to an understanding of the physical nature of the disequilibrium of internal interfaces. The development of the science of nanomaterials made it possible to establish that substances in the nanostate acquire unique physical properties that are significantly different from those that exhibit bulk materials. Also, modern science postulates a direct relationship of the physicochemical characteristics of various substances in the nanostate with some parameters of their electronic structure. Currently, it is believed that the physical properties of NC materials are due to the large contribution of grain boundaries and elastic stresses in the crystal lattice [9]. For each material, there is a characteristic critical size of a structural unit, below which the physical properties of the material change radically. When crystallites are smaller than critical, dislocations and vacancies are pushed from the bulk of the crystal to the grain boundary region.
In this paper, we discuss the results of studies of phase and structural transformations in cobalt nanocrystals obtained through severe plastic deformation (SPD). Deformation is a change in the size and shape of a metal or alloy as a result of external stress. During SPD, metal crystallites are deformed by shifting certain sections of the crystal lattice relative to others. When the load is removed, the displaced part of the crystallites does not return to its original place, the deformation is preserved. The presence of slip lines in a plastic deformed metal is detected visually during microstructural examination of the sample. The phenomenological result of distortion of the crystal lattice of a metal during SPD is hardening, one of the manifestations of which is an increase in strength, which finds practical application for hardening engineering parts. However, it was found that fundamentally new properties in a metal appear only with a sufficient degree of deformation. Therefore, based on this observation, a method for improving the consumer properties of metallic materials is called "severe plastic deformation".

The choice of cobalt as an object of study is due to the following reasons.

- Cobalt can be obtained in the $\mathrm{NC}$ state by the SPD method.

- Cobalt has a relatively low temperature of polymorphic transformation from a hexagonal close packed (hcp) structure to a cubic face-centered (fcc) structure $\left(\sim 427^{\circ} \mathrm{C}\right)$, therefore it is a convenient model object for studying the effect of crystallite sizes and their stress state on the nature of such transitions.

- NC cobalt has a complex phase composition, exhibits anomalous magnetic properties and is characterized by thermal expansion. All this together determines the relevance of the research undertaken in this work.

*mukashev.kms@gmail.com 


\section{METHODOLOGY FOR PREPARING RESEARCH OBJECTS}

To obtain nanostructured cobalt samples in this work, we used the SPD method by torsion under high quasi-hydrostatic pressure in a Bridgman type anvil installation. This nanostructuring method allows one to obtain samples devoid of pores and contaminants, in contrast to the powder compaction technique and the ball grinding method. The high-pressure torsion method is based on metal processing in a plant (Fig. 1), which is often called the Bridgman anvil. The sample is placed inside the cavity of the installation and subjected to SPD by torsion under high pressure due to the rotation of one of the strikers. A high degree of shear deformation is achieved when the number of rotations of the striker is $N>5$, making it possible to obtain nanofragmented metal with a grain size of $10-20 \mathrm{~nm}$. The practical value of the method is limited by the size of the samples, which usually have a disk shape with a diameter of up to $20 \mathrm{~mm}$ and a thickness of up to $1 \mathrm{~mm}$. The practical side of this issue is described in more detail in [10].

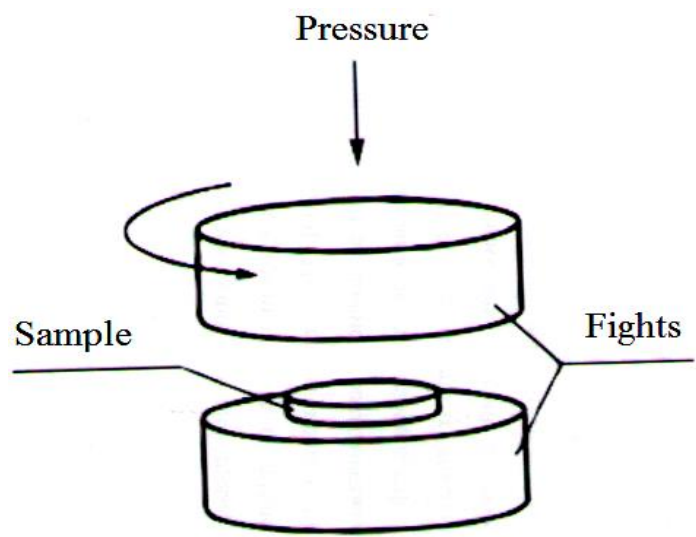

Fig. 1 - Bridgman anvil

\section{X-RAY PHASE ANALYSIS OF RESEARCH OBJECTS}

X-ray studies were carried out on a DRON-7 diffractometer on Co-radiation by the Bragg-Brentano method. A Fe filter was used to suppress the $\mathrm{K}_{\beta}$ line. A scintillation counter was used as a detector. Diffraction patterns were recorded at an anode voltage $U=40 \mathrm{kV}$ and an anodic current $I=20 \mathrm{~mA}$. For phase analysis, $\mathrm{K}_{\alpha}$ lines and Soller slits on the primary and diffracted beams with a divergence of $1.5^{\circ}$ were used.

In this work, the diffraction patterns were recorded from the flat surface of the sample at room temperature. The samples had the form of disks obtained after SPD by torsion under pressure. Interplanar distances were determined by measuring the corresponding diffraction angles of reflection of X-ray radiation according to the Wulf-Bragg formula:

$$
2 d_{h k l} \sin \theta=m \lambda,
$$

where $\lambda$ is the wavelength of X-ray radiation; $\theta$ is the diffraction angle of reflection of X-rays; $d_{h k l}$ is the interplanar distance; $m$ is the order of reflection.
The lattice parameters $a$ and $c$ were determined using the formula

$$
\frac{1}{d^{2}}=\frac{4}{3 a^{2}}\left(h^{2}+h k+k^{2}\right)+\frac{l^{2}}{c^{2}}
$$

with known plane indices $(h k l)$ by the least squares method using a computer program.

\section{ASSESSMENT OF THE SIZE OF THE STRUCTURAL CHARACTERISTICS OF OBJECTS}

Many practically important physical properties of metals depend on the size of the coherent scattering region (CSR) of X-rays and microdeformations in the material. By varying the CSR size and the magnitude of microdeformations, one can change the physical properties of metals and alloys. A decrease in CSR sizes to $1000 \AA$ or less and an increase in microstrains cause an expansion of diffraction lines. In real crystals, the width of diffraction lines is determined by both the CSR sizes and microstrains. Then the resulting broadening of the diffraction line is equal to the sum of broadenings due to microstrains and CSR sizes $[11,12]$ :

$$
W_{L}=\frac{\lambda}{L \cos \theta} \text {. }
$$

Therefore, the contribution of microstrains and CSR sizes to the broadening of X-ray lines varies depending on the diffraction angle $2 \theta$. The study of the dependence of the broadening on $\operatorname{tg} \theta$ and $1 / \cos \theta$ showed that for the initial NC cobalt the dependences

$$
W_{\varepsilon}=4 \varepsilon \cdot \operatorname{tg} \theta
$$

and

$$
W=f\left(\frac{1}{\cos \theta}\right)
$$

can be considered linear. Hence, CSR sizes and microstrains make comparable contributions to X-ray line broadening (Fig. 2).

To confirm the above assumptions, microstrains in the sample were determined by different methods (Fig. 3a). They represent averaged microstrains in the sample over all crystallographic planes, for which maxima are observed in the diffractograms. The values of microstrain determined by different methods differ only for the annealing temperature range below $300{ }^{\circ} \mathrm{C}$. This is due to the fact that at annealing temperatures above $300{ }^{\circ} \mathrm{C}$, the crystallite sizes increase and their contribution to the broadening of X-ray lines decreases. Therefore, in this temperature range, the width of $\mathrm{X}$ ray lines is mainly determined by microstrains in the sample, and all the methods used give close values of $\varepsilon$. In order to clarify the values of microstrain, taking into account the contribution of CSR sizes, they were calculated by the formula obtained as a result of transforming the ratio (3):

$$
\varepsilon=\frac{\left(W-\frac{\lambda}{L \cos \theta}\right)}{4 \operatorname{tg} \theta} .
$$



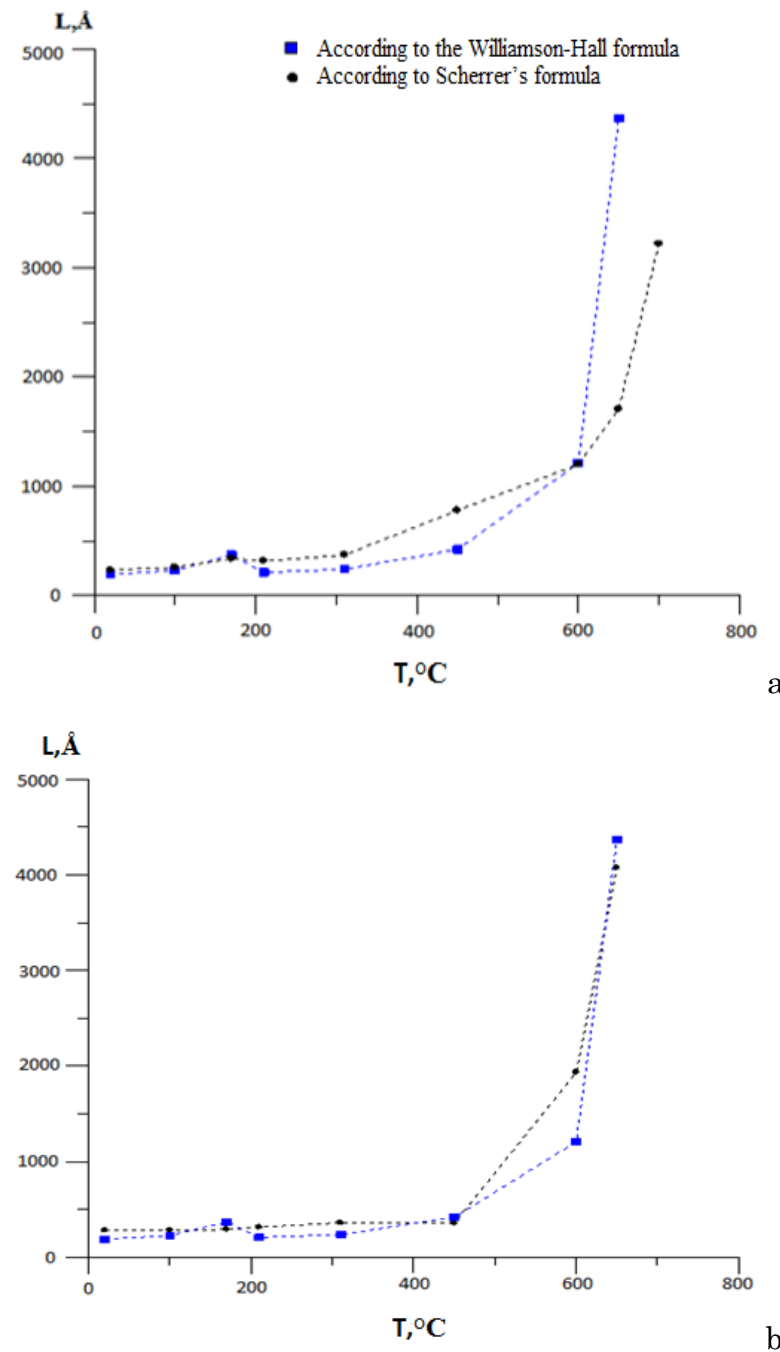

Fig. 2 - Dependence of the CSR sizes of cobalt nanocrystals on the annealing temperature determined from the lines: a) (100), $2 \theta=48^{\circ}$; b) (002), $2 \theta=52^{\circ}$

The calculations used the $L$ values determined from line (112) and took into account their dependence on the annealing temperature (Fig. 3a). As can be seen, the values of microstrain calculated by relation (3) have intermediate values. The values of microstrain calculated by relation (4) for line (103) and determined from the Williamson-Hall curves differ significantly at annealing temperatures above $300{ }^{\circ} \mathrm{C}$, in contrast to microstrains determined for line (112) (Fig. 3b). A possible reason for this is that line (112) for the hcp modification of cobalt $(d / n=1.069 \AA)$ and line (113) for the fcc modification of cobalt $(d / n=1.067 \AA)$ are superimposed. This makes it difficult to separate them, which leads to additional calculation errors. Thus, in the region of small diffraction angles $\theta$, the CSR sizes make the main contribution to the broadening of X-ray lines of $\mathrm{NC}$ cobalt, while in the region of large angles $\theta$ the contributions of the CSR sizes and microstrains are comparable.
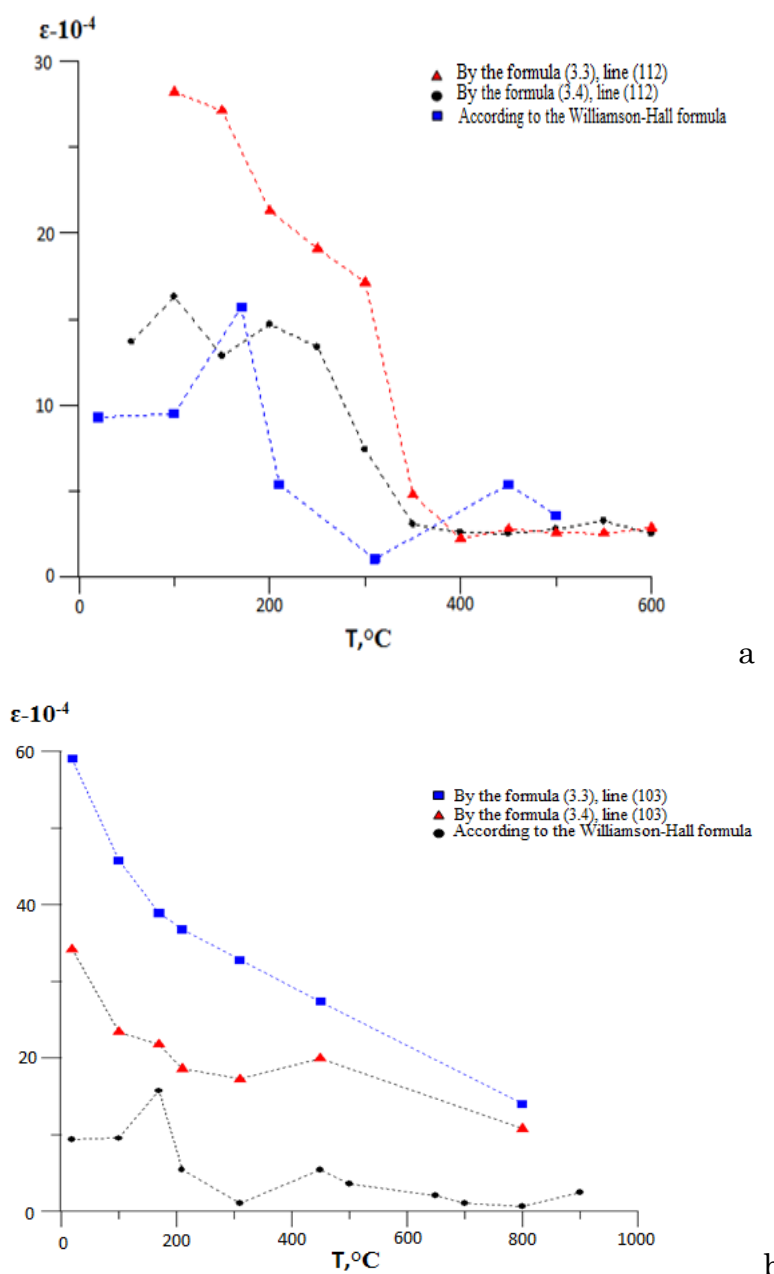

Fig. 3 - Temperature dependence of microdeformation in NC cobalt during annealing determined by different methods

\section{MICROHARDNESS OF NC COBALT}

In this work, the microhardness was determined by the Vickers method by indenting a tetrahedral diamond pyramid with an apex angle of $136^{\circ}$ into the metal. Microhardness was measured on an HVS-1000B device according to the standard method. The microhardness at each point was found from the results of averaging three measurements. The microhardness of a material is determined by its nature, the concentration of point defects and dislocations, as well as their mobility $[13,14]$. The microhardness was measured in the center of the sample, at the edge of the disk, and at a distance equal to half the radius. Fig. 4 shows the microhardness of different parts of the sample depending on the annealing temperature. It is seen that at annealing temperatures up to $\sim 200{ }^{\circ} \mathrm{C}$, the CSR sizes and microhardness HV change only slightly, which is a consequence of the return process in the sample material. At annealing temperatures above $\sim 200{ }^{\circ} \mathrm{C}$, the microhardness in the center of the sample gradually decreases, which is associated with an increase in the crystallite size. In this temperature range, the microhardness at the edge of the disk and at a distance equal to half the radius first increases and then sharply decreases. 


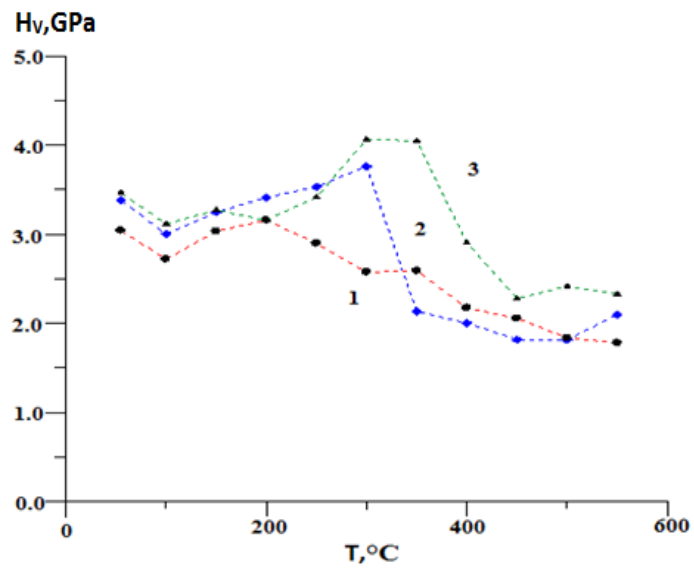

Fig. 4 - The temperature dependence of the microhardness of cobalt nanocrystals upon annealing in different places of the sample: 1 -in the center of the sample; 2 - at a distance from the center equal to half the radius; 3 - at the edge of the sample

The CSR of the X-rays is the smallest region in the form of mosaic blocks, in which there are no distortions of the crystal lattice, more precisely, the disorientation of the crystallographic planes of the same name does not exceed $\sim 1^{\circ} \div 2^{\circ}$. It is known that neighboring blocks are separated by edge dislocations. Therefore, the smaller the block sizes (CSR), the greater the boundaries between the blocks inside the grains, therefore, the higher the density of dislocations. With increasing density of dislocations, hardness increases. Therefore, the increase in microhardness can be explained by a decrease in the CSR size. Fig. 5a shows the dependence of the average microhardness on the average CSR size of $\mathrm{NC}$ cobalt in the coordinates $\mathrm{HV}-f(L-1 / 2)$. It can be seen that this dependence $\mathrm{HV}=f(L-1 / 2)$ consists of two branches. With a decrease in the CSR size to $L \sim 1000 \AA$, the microhardness grows approximately linearly, which can be explained by an increase in the dislocation density. This region corresponds to the region of recrystallization in the structure of $\mathrm{NC}$ cobalt.

As the CSR size decreases below $L \sim 1000 \AA$, the microhardness HV decreases. This region corresponds to the region of return, and the decrease in microhardness with decreasing crystallite size is probably due to a decrease in the resistance of the material to grain boundary sliding. According to another model, a decrease in microhardness in NC materials with a decrease in crystallite size is explained by the initiation of the mechanism of vacancy creep, controlled by grain boundary diffusion of vacancies [15]. This point of view is confirmed by the results of studying the dislocation density as a function of the annealing temperature. The dislocation density was calculated by the formula:

$$
\rho=\frac{W^{2}}{2 b^{2}} \operatorname{ctg}^{2} \theta
$$

where $W$ is the physical line broadening, $b$ is the Burgers vector, which is approximately equal to the lattice parameter of $2.5 \AA$. It was found that in the region of $\mathrm{NC}$ return up to $300^{\circ} \mathrm{C}$, cobalt has a sufficiently high dislocation density, which after annealing in this temperature range up to $300{ }^{\circ} \mathrm{C}$ decreases by only one order of magnitude (Fig. 5b). The reason for this process can be a decrease in the diffusion rate and an increase in microhardness. Therefore, in this region, a weak increase in the crystallite size is accompanied by an increase in microhardness. Subsequently, in the region of recrystallization of cobalt whiskers in the temperature range of $300-350{ }^{\circ} \mathrm{C}$, the dislocation density decreases by two orders of magnitude. With an increase in the annealing temperature, the crystallite size grows, the dislocation density decreases, their mobility increases and the microhardness decreases. Then, the different behavior of the microhardness in the center of the sample and outside it, depending on the annealing temperature, is probably explained by the significantly lower diffusion rate at the center of the sample than at the edge of the disk. Consequently, the degree of deformation and dislocation density increase with the distance from the center of the sample.
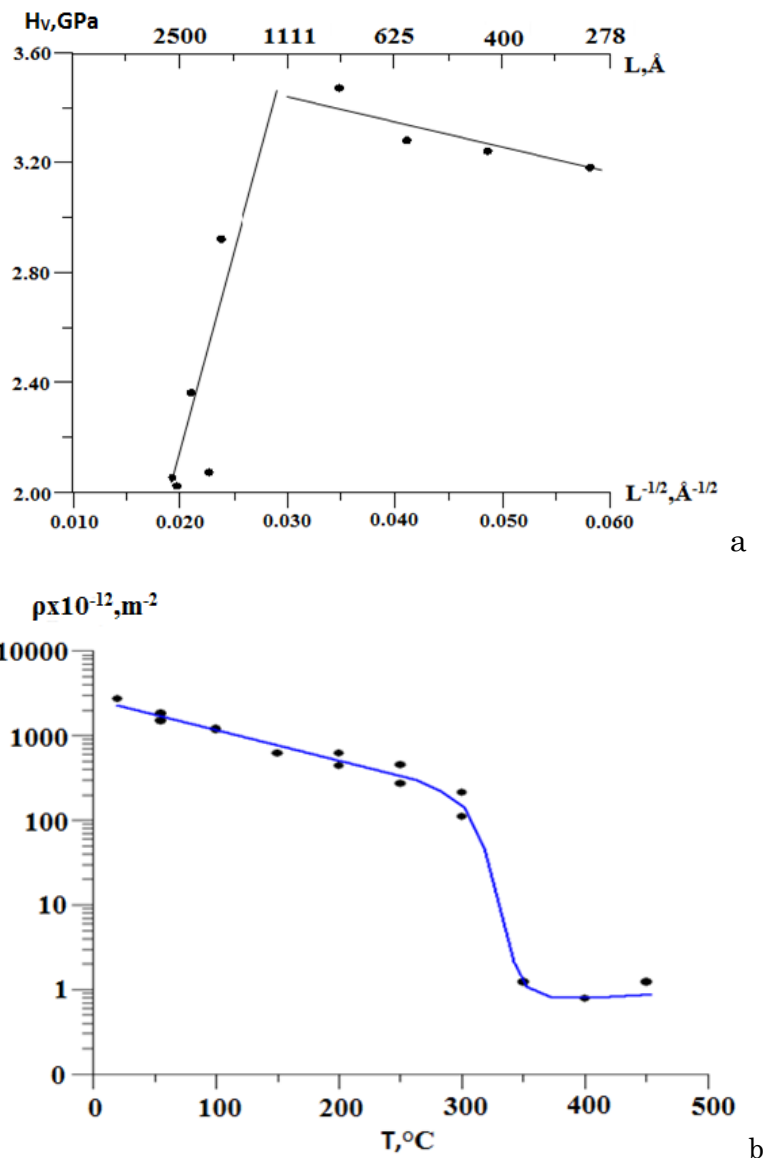

Fig. 5 - Dependence of the average microhardness of cobalt nanocrystals on the CSR size in the $\mathrm{HV}-L-1 / 2$ coordinates (a) and the temperature dependence of the dislocation density in the hcp phase of cobalt nanocrystals upon annealing (b)

\section{TEMPERATURE DEPENDENCE OF THE WIDTH OF THE DIFFRACTION LINES OF COBALT}

Earlier it was found that plastically deformed samples have broad diffraction lines [16]. Upon annealing, the diffraction lines narrow and the $\mathrm{K}_{\alpha}$ doublet is resolved. This indicates the relaxation of crystal lattice defects introduced by plastic deformation and the growth of crystallites [17]. In this regard, the tempera- 
ture dependence of the half-width of X-ray lines upon annealing (the annealing time at each temperature is $40 \mathrm{~min}$ ) is of considerable interest, shown in Fig. 6a for the (002) line. For other lines of NC cobalt, similar dependences are observed. This dependence can be divided into two characteristic regions 1 and 2. Obviously, these regions correspond to the processes of return and recrystallization that occur in the structure of cobalt whiskers by the diffusion mechanism. Therefore, the temperature ranges of changes in the dependence of the width of X-ray lines actually coincide with similar data on changes in the average microhardness and dislocation density (see Fig. 6).
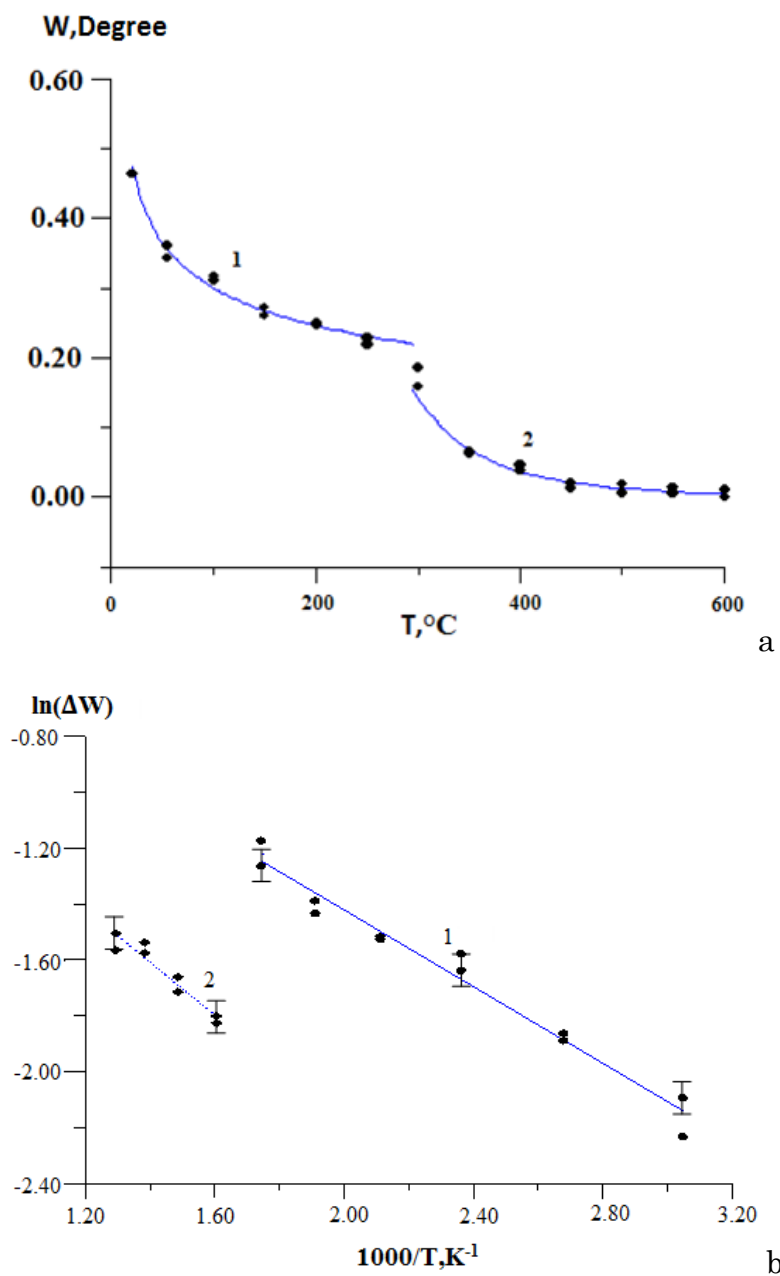

Fig. 6 - Dependences of the width $W$ (a) and $\Delta W$ (b) in coordinates $\ln (\Delta W)=f(1 / T)$ on the annealing temperature for the diffraction line (002) of cobalt nanocrystals

The temperature dependence of the half-width of the (002) line in the coordinates $\ln (\Delta W)-(1 / T)$ is shown in Fig. 6b, whence it can be seen that the dependence $\ln (\Delta W)=f(1 / T)$ is indeed described by two straight lines. Similar dependences are observed for other X-ray lines. The two characteristic regions 1 and 2 identified here with a linear dependence $\ln (\Delta W)=f(1 / T)$ indicate two different processes that occur during annealing in plastically deformed cobalt in different temperature ranges associated with the phenomena of relaxation of defects in the metal structure.

It is known that during annealing of plastically deformed metals and alloys, a return is usually observed at the initial stage, then recrystallization [18]. In this case, during annealing of plastically deformed cobalt in the temperature range up to $\sim 300{ }^{\circ} \mathrm{C}$, it was found that the change in the average crystallite size does not exceed $25-50 \mathrm{~nm}$. Therefore, the low-temperature branch 1 of the dependence $\ln (\Delta W)=f(1 / T)$ describes a decrease in the diffraction line width as a result of the return. At annealing temperatures above $T \sim 300{ }^{\circ} \mathrm{C}$, the dependence $\ln (\Delta W)=f(1 / T)$ is described by another straight line 2, which corresponds to recrystallization in the metal structure. The nature of the linear dependence $\ln (\Delta W)=f(1 / T)$ is of particular interest, since we are not aware of similar data from the literature.

\section{CONCLUSIONS}

Upon annealing of NC cobalt, a similar evolution of the nanostructure is observed. Moreover, the regularities of these processes practically do not depend on the type of crystal lattice, the packing defect energy, which is characteristic of the "usual" processes of recovery and recrystallization. Their influence is overlapped by the intensity of plastic deformation. Three stages of evolution of the Co nanostructure upon heating, obtained by SPD by the torsion method, have been established. At the first stage of heating, called return, in the grain body and at the boundaries, the structure is ordered, which leads to a decrease in the density of point defects and grain boundary dislocations and, as a consequence, partial relaxation of elastic stresses in the grains, as well as redistribution and annihilation of dislocations in the grain body and on borders. At the second stage, a sharp decrease in the concentration of dislocation defects begins as a result of the migration of nonequilibrium boundaries. The process, called recrystallization by the researchers of the behavior of nanocrystals upon annealing, begins at the third stage of evolution, and differs from "ordinary" recrystallization - the nucleation and growth of new grains with highangle boundaries. In this case, the anomalous growth of perfect grains occurs due to the absorption of small imperfect cells. But in both cases, the processes of return and recrystallization occur according to the diffusion mechanism.

The new scientific results obtained in this work allow a deeper understanding of the nature of processes occurring in NDT materials and can be used in the development and creation of new NDT materials, control of their quality, and also identification of new areas of their use.

\section{ACKNOWLEDGEMENTS}

This work was supported by al-Farabi Kazakh National University, Institute of Experimental and Theoretical Physics by AP05130069 project "Development of nanotechnology for the synthesis of functional galvanic coatings for electrical equipment components". 


\section{REFERENCES}

1. S.C. Tjong, H. Chen, Mater. Sci. Eng. R: Report. 45 No 1-2, 1 (2004).

2. H.R. Peng, M.M. Gong, Y.Z. Chen, F. Liu, Int. Mater. Rev. 62 No 6, 303 (2017).

3. L. Tian, Int. J Metall Met. Phys. 2 No 1, 1 (2017).

4. R.A. Muminov, A.K. Saymbetov, N.M. Japashov, Y.K. Toshmurodov, S.A. Radzhapov, N.B. Kuttybay, M.K. Nurgaliyev, J. NanoElectron. Phys. 11 No 2, 02031 (2019).

5. R.A. Muminov, A.K. Saymbetov, N.M. Japashov, A.A. Mansurova, S.A. Radzhapov, B.K. Mukhametkali, N.K. Sissenov, N.B. Kuttybay, J. Semicond. Technol. Sci. 17 No 5, 591 (2017).

6. R.A. Muminov, A.K. Saymbetov, Y.K. Toshmurodov, Instr. Exp. Tech. 56, 32 (2013).

7. R.A. Muminov, S.A. Radzhapov, A.K. Saymbetov, Tech. Phys. Lett. 35, 768 (2009).

8. R.A. Muminov, S.A. Radzhapov, A.K. Saymbetov, Atomic Energy 106 No 2, 141 (2009).

9. A.P. Zhilyaev, T.G. Langdon, Prog. Mater. Sci. 53, 893 (2008).
10. L.A. Gabdrakhmanova, K.M. Mukashev, A.D. Muradov, F.F. Umarov, G.Sh. Yar-Mukhamedova, J. Nano- Electron. Phys. 12 No 1, 01010 (2020).

11. M. Frentrup, L.Y. Lee, S.L. Sahonta, M.J. Kappers, F. Massabuau, P. Gupta, D.J. Wallis, J. Phys. D: Appl. Phys. 50 No 43, 433002 (2017).

12. Q. Feng, C. Jiang, Z. Xu, L. Xie, V. Ji, Surf. Coat. Technol. 226, 140 (2013).

13. R. Kögler, W. Anwand, A. Richter, M. Butterling, X. Ou, A. Wagner, C.L. Chen, J. Nuclear Mater. 427 No 1-3, 133 (2012).

14. K. Lu, Nat. Rev. Mater. 1 No 5, 1 (2016).

15. M.A. Meyers, A. Mishra, D.J. Benson, Prog. Mater. Sci. 51 No 4, 427 (2006)

16. I.C. Dragomir, D.S. Li, G.A. Castello-Branco, H. Garmestani, R.L. Snyder, G. Ribarik, T. Ungar, Mater. Charact. 55 No 1, 66 (2005).

17. X. Sauvage, G. Wilde, S.V. Divinski, Z. Horita, R.Z. Valiev, Mater. Sci. Eng. A 540, 1 (2012).

18. K. Huang, K. Marthinsen, Q. Zhao, R.E. Logé, Prog. Mater. Sci. 92, 284 (2018)

\section{Еволюція нанокристалічної структури кобальту при відпалі}

L.A. Gabdrakhmanova ${ }^{1}$, K.M. Mukashev², F.F. Umarov³, A.D. Muradov², G.Sh. Yar-Mukhamedova²

1 Bashkir State University, Ufa, Bashkortostan, Russia

${ }^{2}$ Al-Farabi Kazakh National University, Almaty, Kazakhstan

${ }^{3}$ Kazakh-British Technical University, Almaty, Kazakhstan

Показано, що межі зерен, утворених в результаті сильної пластичної деформащії кобальту, є висококутовими, нерівноважними, прилеглими до розупорядкованих областей кристалічної решітки. Таке розупорядкування спричинено полями пружних напружень, введеними дислокаціями меж зерен. Густина дислокацій в об'ємі нанокристалів досягає 1010 см². Велика довжина нерівноважних меж та висока густина дефектів відіграють вирішальну роль у формуванні фрізичних і механічних властивостей та визначають низьку термостійкість нанокристалічних матеріалів: ріст зерна починаеться при відносно низьких температурах під час відновлення структури кобальту. Цей процес плавно розвивається до $300{ }^{\circ} \mathrm{C}$. Різка зміна зазначених властивостей відбувається під час рекристалізації при $T>300{ }^{\circ} \mathrm{C}$, і далі властивост практично не змінюються. При $T>400{ }^{\circ} \mathrm{C}$ структура кобальту повністю рекристалізуеться і спостерігаеться подальше укрупнення зерен. У цьому випадку аномальний ріст досконалих зерен відбувається завдяки поглинанню дрібних елементів. У результаті перерозподілу та анігіляції дислокацій в межах та в об'ємі зерен процеси рекристалізації відбуваються у відповідності з дифузійним механізмом.

Ключові слова: Нанокристали, Дифузія, Ріст зерна, Дефекти, Дислокації, Рекристалізація, Енергія активації. 